\title{
Effect of Plant Density on the Water Use Efficiency and Quality of Potato (Solanum tuberosum L. Cv. Spunta) in the Jordan Valley
}

\author{
Nabeel Mohammad Bani-Hani ${ }^{1}$, Jalal "Ahmed Said” Al-Tabbal', Moawiya Ahmad Haddad", \\ Hammad Khalifeh Aldal' in ${ }^{4}$, Ahmad H. Al-Fraihat ${ }^{5}$, Hussein Hussein Alhrout ${ }^{6}$, \\ Hazem Sharef $\operatorname{Hasan}^{7} \&$ Fawzi M. Aldabbas ${ }^{3}$ \\ ${ }^{1}$ National Agricultural Research Center (NARC), Baq'a, Jordan \\ ${ }^{2}$ Department of Nutrition and Food Processing, Al-Huson University College, Al-Balqa Applied University, \\ Irbid, Jordan \\ ${ }^{3}$ Department Nutrition and Food Processing, Faculty of Agricultural Technology, Al-Balqa Applied University, \\ Al-Salt, Jordan \\ ${ }^{4}$ Department of Medical Support, Al-Balqa Applied University, Al-Karak University College, Al-Karak, Jordan \\ ${ }^{5}$ Department of Applied Science, Ajloun University College, Al-Balqa Applied University, Ajloun, Jordan \\ ${ }^{6}$ Department of Medical Allied Sciences, Al-Balqa Applied University, Zarka University College, Zarka, Jordan \\ 7 Department of Plant Production and Protection, Faculty of Agricultural Technology, Al-Balqa Applied \\ University, Jordan \\ Correspondence: Jalal "Ahmed Said" Al-Tabbal, Department of Nutrition and Food Processing, Al-Huson \\ University College, Al-Balqa Applied University, Irbid, Jordan. Tel: 962-797-660-137. E-mail: \\ jaltabbal@bau.edu.jo \\ Hazem Sharef Hasan, Department of Plant Production and Protection, Faculty of Agricultural Technology, \\ Al-Balqa Applied University, Jordan. E-mail: hazem@bau.edu.jo
}

Received: August 4, 2018

doi:10.5539/jas.v10n12p203
Accepted: September 8, $2018 \quad$ Online Published: November 15, 2018

URL: https://doi.org/10.5539/jas.v10n12p203

\begin{abstract}
Plant density affected yield, quality and water use efficiency. Little information describing plant density to optimize yield and quality of potato production is available in the Jordan Valley. This study was aimed to investigate the effects of plant density on the yield and yield components of the potato (Solanum tuberosum L.) cultivar "Spunta" grown in the middle of the Jordan Valley. Five different densities of plants $\left(41,600\right.$ plants ha $^{-1}$

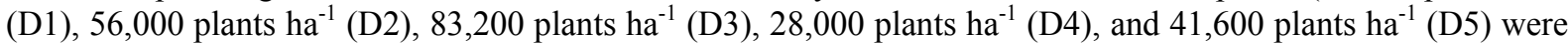
randomly distributed over five replicate sites during the growing season from November 2013 to March 2014. Plant height, number of branches, fresh and dry weight of potato plants, tuber number, tuber weight, total yield, specific gravity and water use efficiency of potato plant grown under different plant density were measured. It was found that the productivity of potato increased with increasing plant density, with the highest total, marketable, and non-marketable yields being obtained at densities of 83,200 seeds $\mathrm{ha}^{-1}$, and the lowest occurring at 41,600 seeds $\mathrm{ha}^{-1}$, which equated to total fresh yields of 45.1 and 25.3 tons $\mathrm{ha}^{-1}$, respectively. The highest water use efficiency for marketable yield $\left(11.9 \mathrm{~kg} \mathrm{~m}^{-3}\right)$ was obtained at a density of 83,200 seeds ha ${ }^{-1}$, whereas the lowest water use efficiency $\left(7.5 \mathrm{~kg} \mathrm{~m}^{-3}\right)$ was obtained at a density of 41,600 seeds ha ${ }^{-1}$. The specific gravity ranged from 1.04 to 1.08 and the average tuber weight ranged from $77.02 \mathrm{~g}$ at a density of $83,200 \mathrm{seeds} \mathrm{ha}^{-1}$ to $115.84 \mathrm{~g}$ at a density of 28,000 seeds $\mathrm{ha}^{-1}$.
\end{abstract}

Keywords: potato, plant density, quality, water use efficiency

\section{Introduction}

Potato (Solanum tuberosum L.) is one of the most important food crops in the world (Jr et al., 2013) after wheat (Triticum aestivum), rice (Oryza sativa), and corn (Zea mays) (Calabrese, 2011). The high carbohydrate and low fat contents of potato make it an excellent energy source for human consumption. In Jordan, approximately 216,483 tons of potato is produced over a total area of approximately 5885 ha. Potato is grown in two major regions in Jordan: the highland area and the Jordan Valley. In the highland area, approximately 4397 ha were 
planted in potato in 2011, with a total production of 170,230 tons and an average yield of approximately 38.7 tons $\mathrm{ha}^{-1}$. By contrast, in the Jordan Valley, approximately 1488.4 ha were planted in potato in 2011, with a total production of 46,253 tons and an average yield of 31.1 tons $\mathrm{ha}^{-1}$. The total area planted in potato in Jordan increased from 3500 ha in 2002 to 5885 ha in 2011, with an associated production increase from 105,300 tons to 216,483 tons.

The growth, development and yield of potato are governed by a number of factors, including the availability of nutrients (Haddad et al., 2016), cultivar, plant density, and environmental conditions (Arsenault et al., 2001). Onunka et al. (2011) noticed that crops output can be strongminded by cultivar and plant population. Plant density which can be a result of plant arrangement affects competition for growth incomes. Two components can be utilized to identify plant density. The first one is the number of plants generally referred to as plant density and the second is referred as the number of stem per plants (Shayanowako et al., 2014). Plant density is the most important factors affecting potato production because it affects plant growth, yield, and the quality of the crop (Bussan et al., 2007) through its effects on the weight and number of tubers (Getachew et al., 2013). Increasing plant density may cause in growth and yield decrease per plant by producing a greater number of tubers (Khajehpour, 2006) and a lower mean tuber size due to increased inter-plant competition for water, light, and nutrients. However, a higher plant density might pay off for plant density-induced decreased growth and yield. The increasing number of tubers compensates for the associated decrease in tuber weight (Arab et al., 2011), resulting in a yield increase in potato at higher densities (Bussan et al., 2007).

Since plant density affects plant development, yield, and quality, as well as seed costs (Bussan et al., 2007), it is essential to determine the crop density that optimizes yields. Less is identified about the mechanisms through which tuber yield are affected by planting density. Therefore, the main objective of this study was to determine the effect of plant density on the vegetative growth, yield, quality, and water use efficiency (WUE) of field-grown potatoes.

\section{Materials and Methods}

The experiments were conducted in the middle Jordan Valley during autumn 2012 till spring 2014. Tubers of the potato cultivar "Spunta" were planted at five different densities with five replicates per treatment: D1 (41,600 plants ha $\left.{ }^{-1}\right)$, D2 (56,000 plants ha $\left.{ }^{-1}\right)$, D3 (83,200 plants ha $\left.{ }^{-1}\right)$, D4 (28,000 plants ha $\left.{ }^{-1}\right)$, and D5 (41,600 plants ha $\left.{ }^{-1}\right)$. The differences between these densities resulted from differences in the inter-row spaces and number of plants per dripper in the drip irrigation system. Thus, rows were spaced at $0.6 \mathrm{~m}$ for D1 and D3 with one and two plants per dripper, respectively; at $0.9 \mathrm{~m}$ for D2 and D4 with two plants and one plant per dripper, respectively; and at $1.2 \mathrm{~m}$ for D5 with two plants per dripper.

Potato tubers (average weight $=109.3 \mathrm{~g}$ ) were planted on November 26,2013 in $30 \mathrm{~m}^{2}$ plots $(5 \times 6 \mathrm{~m})$ at a depth of $0.1 \mathrm{~m}$ from the soil surface. The potatoes were planted in a raised soil bed with no added plastic mulch so that they would benefit from rainfall. In addition, the soil was mounted around the plant stems 45 days after planting and on two other occasions at intervals of 2-3 weeks to increase productivity and improve the quality of the potato tubers by protecting them from exposure to the sun and from forming toxic materials (blue color).

Productivity was measured by harvesting the middle row from each plot. After harvesting, the tubers from each treatment were separated into marketable and non-marketable products, which were each classified into three grades according to their weight: grade a, $>120 \mathrm{~g}$; grade b, 81-120 g; and grade c, $<80 \mathrm{~g}$. The dry weight of the vegetative growth of the whole plant was also determined by drying the aerial parts of three plants from each replicate of each treatment at $65{ }^{\circ} \mathrm{C}$ for $72 \mathrm{~h}$. The specific gravity of the tubers was also determined for subsamples of acceptable tubers by dividing the tuber weight in air by the tuber weight in water.

\subsection{Experimental Conditions}

Aside from density, all other growing conditions were fixed across treatments. The quantity of fertilizer to be added was determined by taking composite soil samples and analyzing nutrient levels in the surface soil layer $(0-30 \mathrm{~cm})$ and subsurface soil layer $(30-60 \mathrm{~cm})$ (Table 1).

Table 1. Chemical and physical soil properties of experimental site

\begin{tabular}{|c|c|c|c|c|c|c|c|c|}
\hline Soil Depth & $\mathrm{PH}$ & $\mathrm{EC}$ & $\mathrm{N}$ & $\mathrm{P}$ & $\mathrm{K}$ & $\mathrm{CaCO}_{3}$ & $\mathrm{OM}$ & Texture \\
\hline ----- cm ----- & - & $\mathrm{ms} / \mathrm{cm}$ & ---- \% ---- & \multicolumn{2}{|c|}{---------- ppm ---------- } & \multicolumn{2}{|c|}{ |------------ \% ------------ } & - \\
\hline $0-30$ & 7.7 & 0.85 & 0.190 & 12.2 & 527 & 14.8 & 1.20 & Clay \\
\hline $30-60$ & 7.8 & 1.32 & 0.106 & 8.2 & 473 & 16.1 & 0.80 & Clay loam \\
\hline
\end{tabular}


The amount of irrigation required per unit planted area was calculated from meteorological data, using the Penman-Monteith equation of the Food and Agriculture Organization (Allen et al., 1998) to determine potential evapotranspiration $\left(\mathrm{ET}_{0}\right)$. The actual crop water requirement was then obtained by multiplying the crop coefficient $(\mathrm{Kc})$ for potato by $\mathrm{ET}_{0}$, using an irrigation efficiency of $85 \%$ and a leaching fraction of 0.15 to correct the amount of irrigation. Thus, the total quantity of irrigation water that was applied in addition to the effective rainfall was $300 \mathrm{~mm}$. A water meter was used to control the quantity of irrigated water applied through an inline drip irrigation system (GR) with a space of $0.4 \mathrm{~m}$ between emitters and an average emitter discharge of $41 \mathrm{~h}^{-1}$. Before planting, organic manure was distributed over the soil surface at a rate of 5 tons ha ${ }^{-1}$ and incorporated into the soil to improve soil fertility and the physical soil properties (Table 2).

Table 2. Organic manure analysis of cow incorporated with surface soil layers

\begin{tabular}{lccl}
\hline Nitrogen & Phosphorus & Potassium & Moisture content \\
\hline$-\cdot 4.4$ & 2.2 & 5.3 & 72 \\
\hline
\end{tabular}

Amara and Mourad (2014) found that mixed manure significantly increased the number of tubers per plant and the percentage of standard tubers compared with a control treatment. It was found that there was already sufficient $\mathrm{N}$ and $\mathrm{K}$ in the soil to give an expected yield of 50 tons $\mathrm{ha}^{-1}$. Therefore, only a small amount of P (42 $\left.\mathrm{kg} \mathrm{ha}^{-1}\right)$ needed to be added, which was supplied through the injection of $70 \%$ phosphoric acid $\left(1001 \mathrm{ha}^{-1}\right)$ distributed over four irrigation periods spanning 4 weeks from 50 days after planting. Soil moisture samples $(0-30 \mathrm{~cm}, 30-60 \mathrm{~cm}$, and $60-90 \mathrm{~cm})$ were taken from each experimental plot on the day of planting and at harvest to determine the change in soil moisture content. The average quality of the irrigation water that was used to irrigate the plants is shown in Table 3. The salinity of the irrigation water was lower than the threshold concentration $\left(2.5 \mathrm{dS} \mathrm{m}^{-1}\right)$ that can be tolerated by cultivar "Spunta" (Katerji et al., 2000).

Table 3. Water quality used in irrigation along the growing season

\begin{tabular}{|c|c|c|c|c|c|}
\hline Month & Nov. 2013 & Dec. 2013 & Jan. 2014 & Feb. 2014 & March. 2014 \\
\hline $\mathrm{pH}$ & 8.7 & 8.7 & 8.7 & 8.7 & 8.7 \\
\hline $\mathrm{EC} \mathrm{dS} \mathrm{m}{ }^{-1}$ & 1.5 & 1.5 & 1.4 & 1.4 & 1.6 \\
\hline Available N (ppm) & 10.8 & 8.1 & 8.2 & 8.8 & 9.2 \\
\hline P mg (ppm) & 0.92 & 0.85 & 0.92 & 0.90 & 0.86 \\
\hline $\mathrm{K}(\mathrm{ppm})$ & 16.8 & 12.9 & 13.7 & 14.8 & 15.2 \\
\hline Na me $1^{-1}$ & 7.7 & 6.7 & 8.1 & 8.0 & 6.5 \\
\hline $\mathrm{Mg} \mathrm{me}^{-1}$ & 2.5 & 3.5 & 3.9 & 8.2 & 1.2 \\
\hline $\mathrm{Ca} \mathrm{me}^{-1}$ & 4.0 & 3.6 & 4.2 & 3.6 & 5.2 \\
\hline SAR & 4.3 & 3.7 & 4.0 & 4.1 & 3.7 \\
\hline
\end{tabular}

The average monthly maximum, minimum, and average temperatures, relative humidity, and wind speed over 10 years from 2003 to 2013 and during the growing period in the current experiment from November to March 2014 are shown in Table 4. The total rainfall during the growing season was $250 \mathrm{~mm}$, of which only $175 \mathrm{~mm}$ was considered effective (75\%).

Table 4. Meteorological characteristics of the experimental site along growing season

\begin{tabular}{llllll}
\hline Month & Rainfall $(\mathrm{mm})$ & Relative humidity $(\%)$ & $\mathrm{T} \max \left({ }^{\circ} \mathrm{C}\right)$ & $\mathrm{T} \min \left({ }^{\circ} \mathrm{C}\right)$ & $\mathrm{ET}(\mathrm{mm})$ \\
\hline December, 2012 & 26.9 & 54.4 & 22.7 & 14.5 & 65 \\
January, 2013 & 131.6 & 53.6 & 20.2 & 12.4 & 66.7 \\
Februarys, 2013 & 17.5 & 52.6 & 23.4 & 14 & 85.2 \\
March, 2013 & 0.75 & 38.8 & 27.9 & 14.9 & 141.4 \\
April, 2013 & 0 & 34.3 & 31.6 & 19.4 & 156.0 \\
December, 2013 & 18 & 48.5 & 22.3 & 18.6 & 66 \\
January, 2014 & 141 & 55 & 20.4 & 12.1 & 68 \\
Februarys, 2014 & 19 & 54.4 & 22.5 & 13 & 86.3 \\
March, 2014 & 3 & 47.9 & 26.5 & 15.5 & 151 \\
April, 2014 & 2 & 39 & 33 & 20.1 & 158 \\
\hline
\end{tabular}


The WUE for each treatment was calculated as the tuber yield divided by the seasonal evapotranspiration level $(\mathrm{ETa})$, i.e., $\mathrm{WUE}=$ Yield $(\mathrm{kg}) / \mathrm{ETa}\left(\mathrm{m}^{3}\right)$.

\subsection{Statistical Analysis}

The differences between treatments were determined by analysis of variance (ANOVA) using the Generalized Linear Model (GLM) procedure (Institute, 2006). The treatment means were then compared using Fisher's Least Significant Difference (LSD) test at the 5\% significance level.

\section{Results}

The effect of plant density on the water use efficiency, growth and yield parameters of potato from the two experiments in the year 2012-2013 and 2013-2014 were similar hence the data were pooled together and analyzed.

\subsection{Vegetative Growth}

The effect of plant density on the height of potato plants is shown in Figure 1a. It was found that plant height significantly differed between treatments, being $13 \%$ higher at a high plant density (D3, 83,200 plants ha ${ }^{-1}$ ) than at a low plant density (D1, 41,600 plants $\mathrm{ha}^{-1}$ ) when plants were grown at the same inter-row distances; and a similar trend was observed between D2 and D4, which also represented different densities grown at the same inter-row distances. Furthermore, plant height was greater with wider inter-row spacings (D5, $1.2 \mathrm{~m})$ than with narrower inter-row spacings (D1, $0.6 \mathrm{~m})$ when the density was the same.

In contrast to plant height, the number of branches per plant decreased as the plant density increased (Figure 1b), with plants grown at 28,000 plants ha ${ }^{-1}$ (D4) having significantly more branches than those grown at 41,600 plants ha ${ }^{-1}$ (D1). By contrast, there was no difference in the number of branches per plant for treatments with similar plant densities but different inter-row spacing's (D5 and D1).

In terms of above-ground fresh and dry weights, the highest weights (133.2 g and $26.5 \mathrm{~g}$, respectively) were recorded for plants at a low plant density, whereas the lowest weights (116.97 $\mathrm{g}$ and $21.14 \mathrm{~g}$, respectively) were obtained at a high plant density $(50 \times 20 \mathrm{~cm})$ (Figure $1 \mathrm{c} \& \mathrm{~d})$. This may have been due to plants at a low density having lower levels of competition for growth requirements than those at a high density.

\subsection{Yield and Yield Components}

The major yield components for potato are tuber number and weight. Plant density had a significant effect on yield and the entire yield components measured. Potato tubers were graded into three classes on the basis of weight (grades a-c), each of which was classified into marketable and non-marketable products. The total number of tubers, weight of tubers, and total yield per ha were then calculated for each category.

There was a significant increase in the total number of tubers with increasing plant density (Figures 1a-1d)

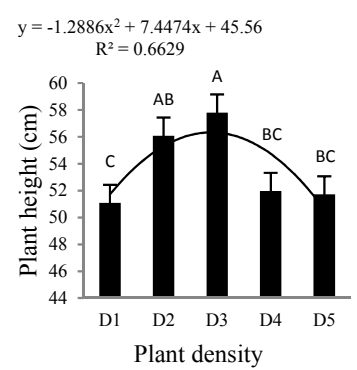

a

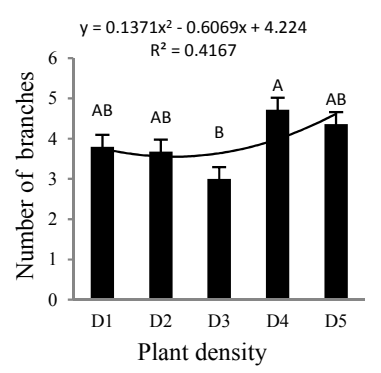

$\mathrm{b}$

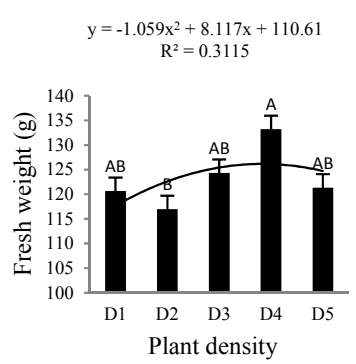

$\mathrm{c}$

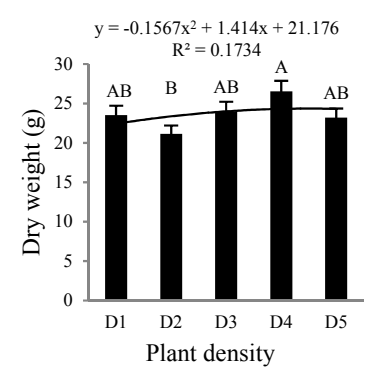

d

Figure 1. Plant height, number of branches, fresh and dry weight of potato plants grown under different plant density

The highest total number of tubers $(596,000)$ was obtained at a plant density of 83,200 plants $^{-1}{ }^{-1}$ (D3) and this was $13 \%$ higher than that at 41,600 plants $^{-1} \mathrm{a}^{-1}$ (D1), which had the same inter-row spacing. Investigation of the different grades showed that plants that were grown at a higher density (D3) produced $100 \%$ and $200 \%$ more grade $\mathrm{b}$ and $\mathrm{c}$ tubers, respectively, whereas there was no significant increase in the number of grade a tubers. A similar trend was observed for the number of marketable and non-marketable tubers, with significantly more tubers from each category being produced at the highest plant density (D3). By contrast, there was no significant 
difference in the total number of tubers per plant in either the marketable of non-marketable category between plants that were grown at different inter-row spacings (0.6 m [D1] vs. $1.2 \mathrm{~m}$ [D5]). This difference in the total number of tubers produced at different densities supports the results obtained by Khajehpour (2006).

Although there was no significant improvement in the number of larger (grade a) potatoes (both marketable and non-marketable) produced, the number of smaller and medium-sized potatoes (grades b and c) significantly increased, highlighting a qualitative deterioration in tuber yield with increasing plant density. Indeed, at the highest plant density (D3) there was a significantly higher yield of $b$ and $\mathrm{c}$ grade tubers for marketable $(96,000$ and $136,000 \mathrm{ha}^{-1}$, respectively) and non-marketable (14,000 and 221,333 $\mathrm{ha}^{-1}$, respectively) tubers than at lower plant densities (Figures 2g-21).

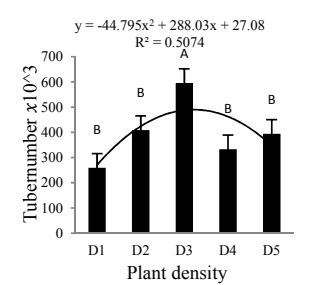

a

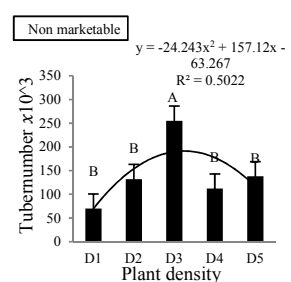

$\mathrm{f}$

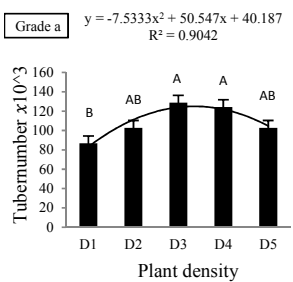

$\mathrm{b}$

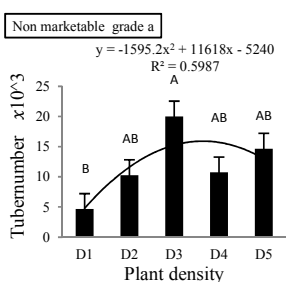

g

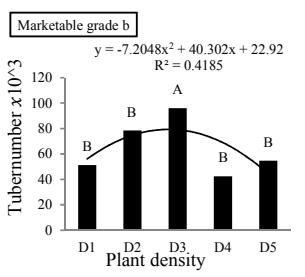

k

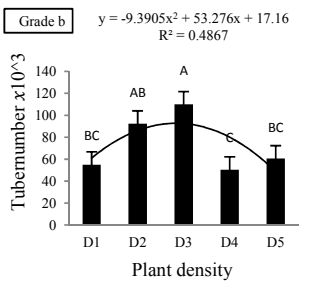

c

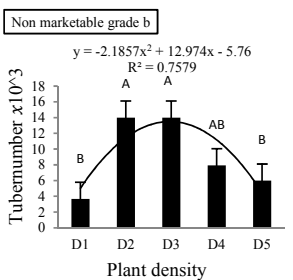

h

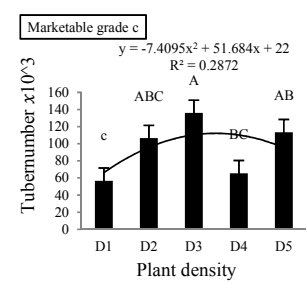

1

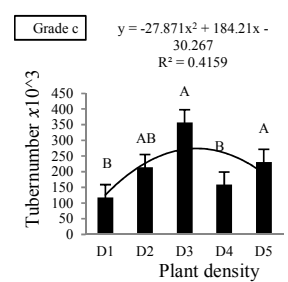

d

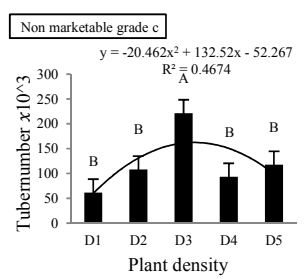

i

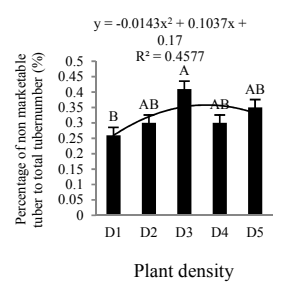

m

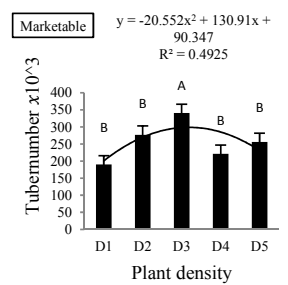

e

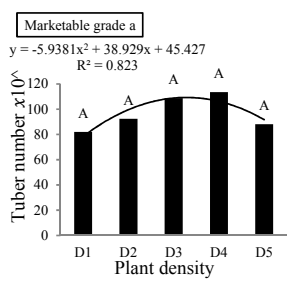

Figure 2. Tuber number (marketable, non-marketable, grade a\&b\&c) of potato plants grown under different plant density

The highest average tuber weight $(115.84 \mathrm{~g})$ was recorded for plants that were grown at the lowest plant density (28,000 plants ha ${ }^{-1}$ with one plant per dripper; D4), followed by 41,600 plants ha $^{-1}$ and one plant per dripper (D1), while the lowest average tuber weight $(77.02 \mathrm{~g})$ was obtained at the maximum plant density $\left(83,200\right.$ plants ha $^{-1}$ with two plants per dripper; D3). In addition, the three treatments with two plants per dripper (D2, D3, and D5) had significantly lower tuber weights $(23.24 \%, 33.51 \%$, and $27.33 \%$, respectively) compared with the lowest plant density with one plant per dripper (D4) (Figure 3a). Similar trends were observed for the weight of marketable tubers and grade a tubers from this class (Figures 3b-3c). By contrast, there was no significant difference in the tuber weight of grade $\mathrm{b}$ and $\mathrm{c}$ marketable potatoes and all grades of non-marketable potatoes between different plant densities, with the lowest plant density and the highest plant density producing the highest and lowest values for tuber weight, respectively (Figures 3d-3i). The highest percentage of tuber weight for grade a $(69.1 \%)$ was obtained with the lowest plant density (D4), which also gave a higher average fruit weight (199.7 g) (Table 5). 
Table 5. Tuber weight percentage for grade $\mathrm{a}, \mathrm{b} \& \mathrm{c}$

\begin{tabular}{llll}
\hline \multirow{2}{*}{ Treatments } & \multicolumn{3}{c}{ Tuber weight (\%) } \\
\cline { 2 - 4 } & Grad a & Grade b & Grade c \\
\hline D1 & 61.0 & 21.2 & 17.8 \\
D2 & 53.3 & 24.8 & 21.8 \\
D3 & 49.5 & 23.6 & 26.9 \\
D4 & 69.1 & 14.1 & 16.8 \\
D5 & 56.3 & 18.2 & 25.5 \\
\hline
\end{tabular}

By contrast, the lowest percentage of tuber weight (49.5\%) was obtained with the highest plant density (D3), which also gave the lowest average fruit weight $(173.7 \mathrm{~g})$. The opposite result was obtained for grade $\mathrm{c}$, for which D3 and D5 gave the highest percentage of tuber weight values (26.9\% and $25.5 \%$, respectively) but the lowest average fruit weights (33.9 $\mathrm{g}$ and $36.1 \mathrm{~g}$, respectively), which was attributed to the higher plant density and lower inter-row spacing.

The yield of mature tubers at the whole plot level significantly differed between the five plant densities, with significantly higher values being observed at a low plant density (D4: 45.1 tons $^{-1} \mathrm{~h}^{-1}$ ) than at a high plant density (D1: 15.441 tons $\mathrm{ha}^{-1}$ ) in treatments with the same inter-row spacing (Figure 4a). With respect to potato size categories, the yield of grade $b$ and $c$ tubers was significantly higher at a higher plant density (Figures $4 b-4 d$ ). Plant density also had a significant effect on the non-marketable yield and a similar but insignificant effect on the marketable yield (Figures 4e-4f), with the highest yields for both (marketable, 35.84 tons ha $^{-1}$; non-marketable, 9.26 tons $\mathrm{ha}^{-1}$ ) being obtained in the plots with the highest plant density. Plant density also affected the marketable yield of grade c tubers, with the highest plant density having a $157 \%$ higher yield than the lowest density, and the non-marketable yield of grade b and c tubers, which were $319 \%$ and $189 \%$ higher, respectively, in plants grown at a high density compared with those grown at a low density with the same inter-row spacing (Figure 4g-1).

The highest percentage of non-marketable yield was obtained with the D3 treatment $\left(83,200\right.$ plants $^{-1}{ }^{-1}$, whereas the lowest was obtained with the D1 treatment $\left(41,600\right.$ plants ha $^{-1}$ ) (Figure $\left.4 \mathrm{~m}\right)$. By contrast, the highest percentage of marketable yield (88.9\%) was obtained with the D1 treatment (grade a, 57.7\%; grade b, 19.82\%; and grade c, $11.29 \%$ ), whereas the lowest (79.5\%) was obtained with the D3 treatment (grade a, $42.7 \%$; grade b, $20.4 \%$; and grade c, $16.3 \%$ ) (Figure 4). It was found that the percentage of non-marketable yield was higher for grade $\mathrm{c}$ than for grades $\mathrm{b}$ and a (Table 6), with the overall highest percentage of non-marketable yield (38.1\%) being obtained for grade $\mathrm{c}$ with the D3 treatment, which had the highest plant density and thus the greatest amount of competition between tubers, which yielded large quantities of small potato tubers. By contrast, the lowest percentage of non-marketable yield $(5.7 \%)$ was obtained for grade a with treatment D1 due to the lower plant density and thus lower levels of competition among tubers, as well as the increased ease of moving between the rows and mounting soil above the tubers that were produced. 

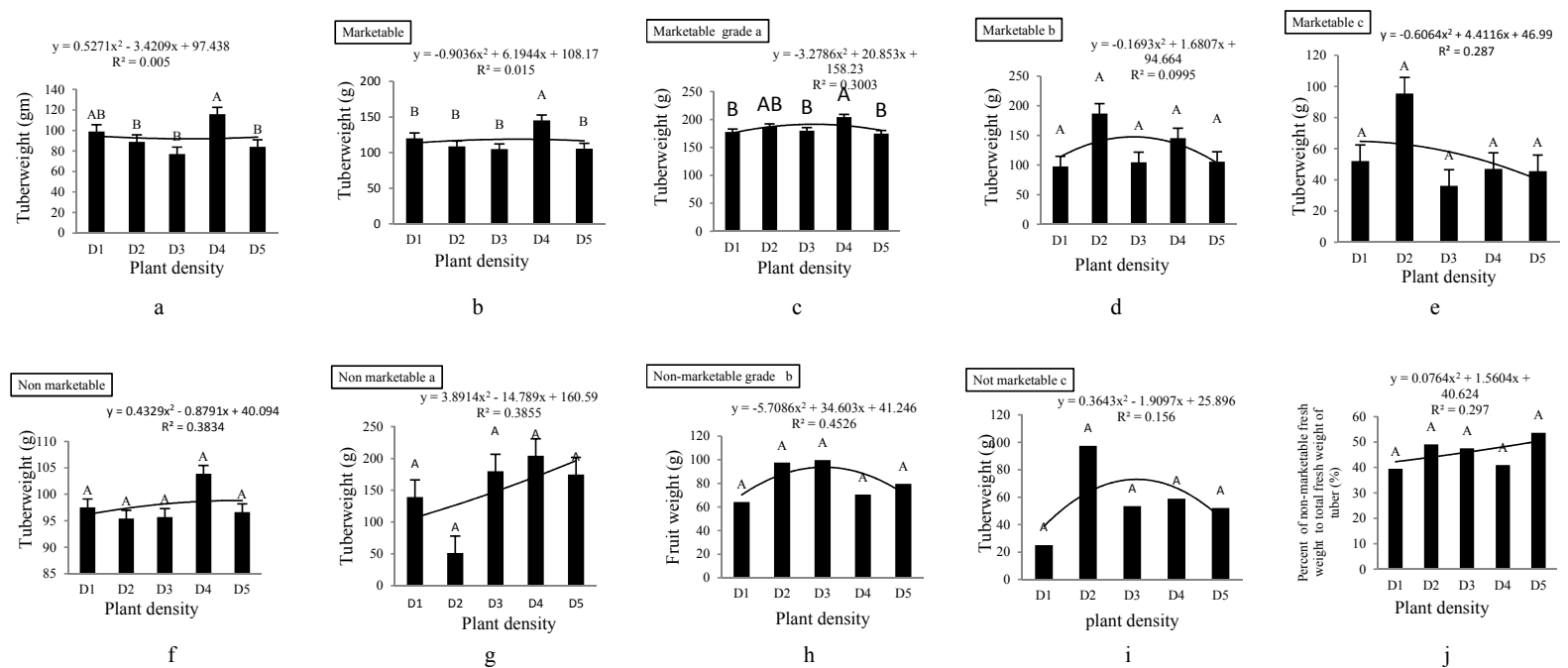

Figure 3. Tuber weight (marketable, non-marketable, grade a \& b \& c) of potato plants grown under different plant density

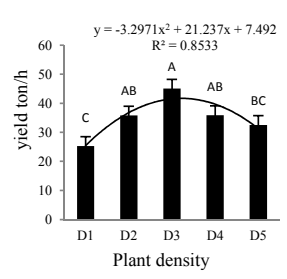

a
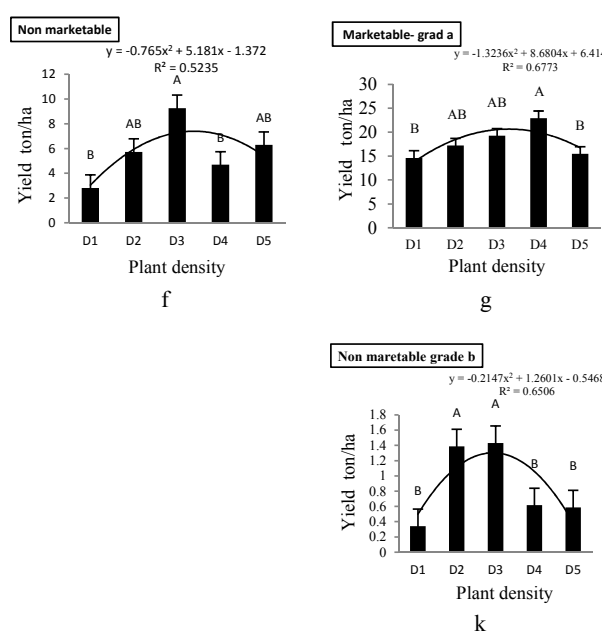
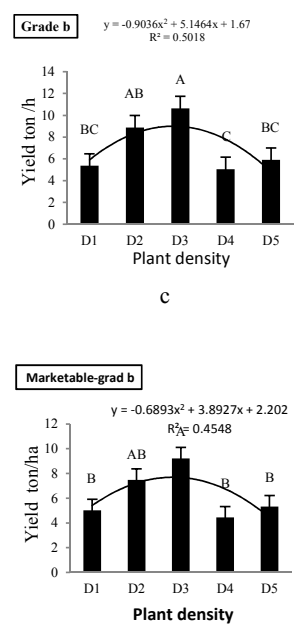

$\mathrm{h}$

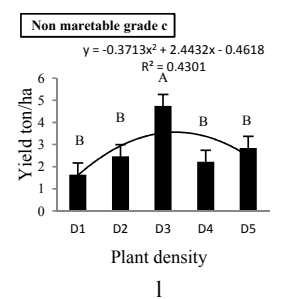

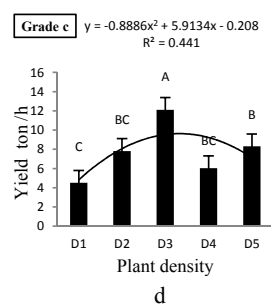
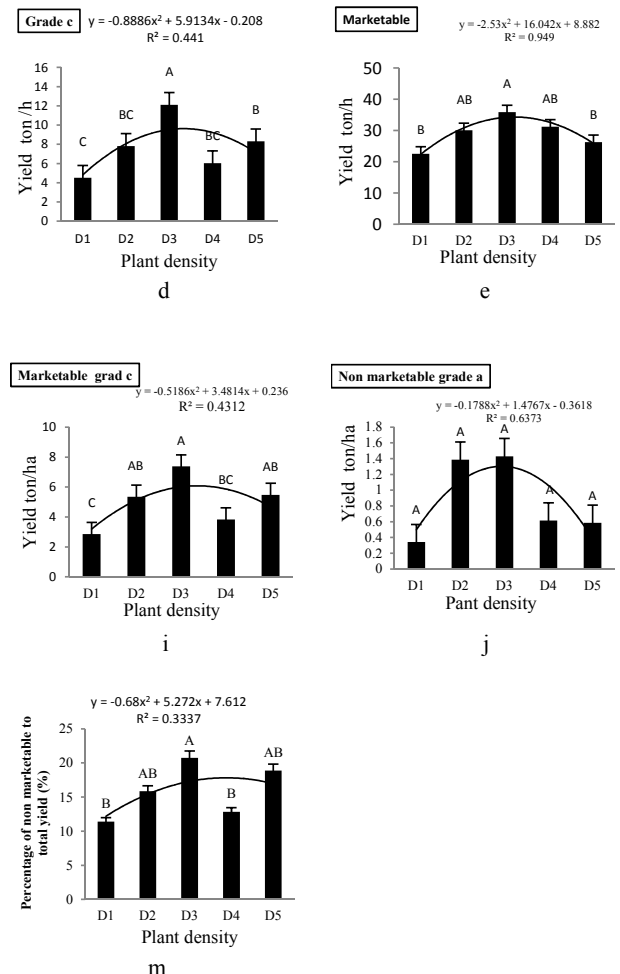

Figure 4. Tuber yield (marketable, non-marketable, grade a \& b \& c) of potato plants grown under different plant density 
Table 6. Non-marketable yield percentage for grade $\mathrm{a}, \mathrm{b} \& \mathrm{c}$

\begin{tabular}{llll}
\hline \multirow{2}{*}{ Treatment } & \multicolumn{3}{c}{ Non Marketable yield (\%) } \\
\cline { 2 - 4 } & Grad a & Grad b & Grad c \\
\hline D1 & 5.7 & 7.3 & 33.5 \\
D2 & 10.0 & 15.9 & 30.5 \\
D3 & 14.5 & 13.5 & 38.1 \\
D4 & 7.4 & 15.2 & 36.8 \\
D5 & 14.4 & 9.7 & 34.3 \\
\hline
\end{tabular}

\subsection{Tuber Quality}

Several quality parameters are used in the potato processing industry. However, the most important of these is specific gravity, which is an expression of density that gives an indication of the dry matter content of the tubers. The specific gravity of tubers showed a decreasing trend with increasing plant density. However, these differences were not statistically significant (Figure 5).

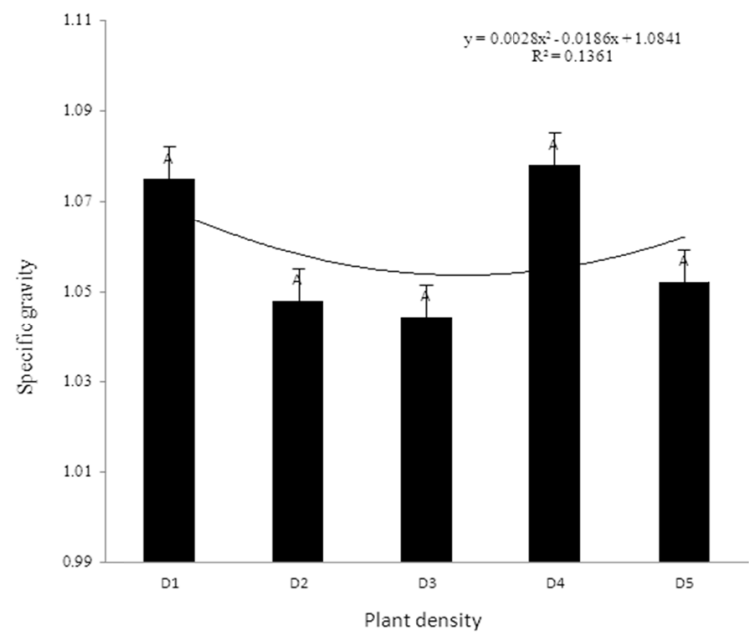

Figure 5. Specific gravity of potato plants grown under different plant density

\subsection{Water Use Efficiency}

Plant density significantly affected WUE, which is expressed as yield in $\mathrm{kg}$ per $\mathrm{m}^{3}$ of irrigation water used (Figure 6a). The maximum WUE $\left(15 \mathrm{~kg} \mathrm{~m}^{-3}\right)$ was observed under a high plant density, while the minimum ( 8.3 $\mathrm{kg} \mathrm{m}^{-3}$ ) occurred with a low plant density. This increased WUE with increasing density may be due to high density planting accommodating a higher density of roots, which enables the plants to extract larger amounts of water than occurs at a low density. The minimum WUE may have occurred under a low plant density due to increased levels of evaporation. The WUE for grade a and b potato tubers was $168 \%$ and $98 \%$ higher, respectively, in plants that were grown at the highest plant density (D3) than in those that were grown at a low plant density (Figure 6b-6c). Similar trends were also obtained for marketable and non-marketable products (Figures 6e-61). 


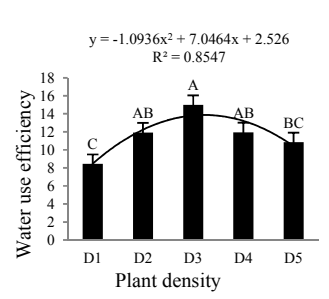

a

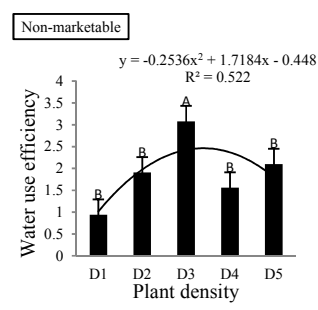

e

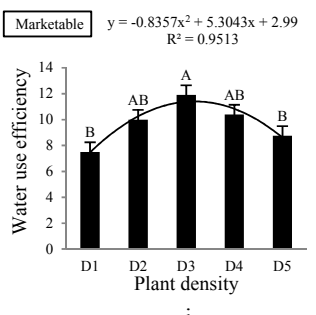

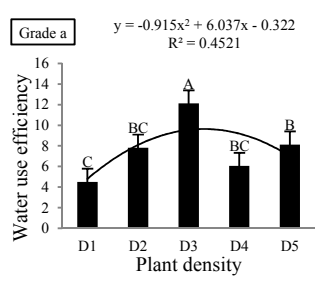

b

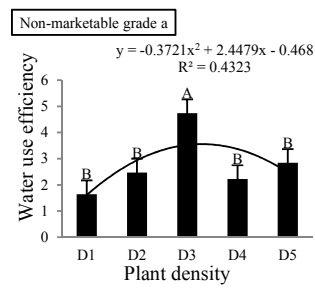

f

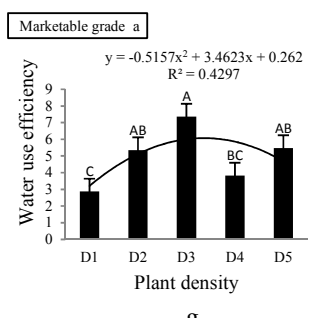

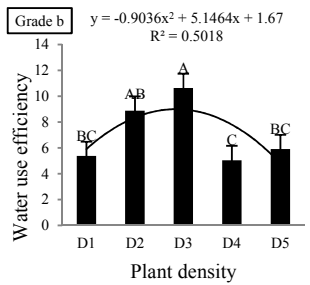

c

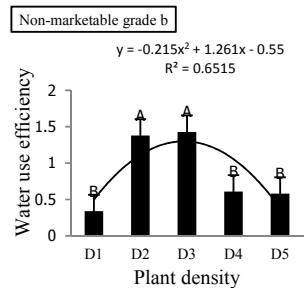

g

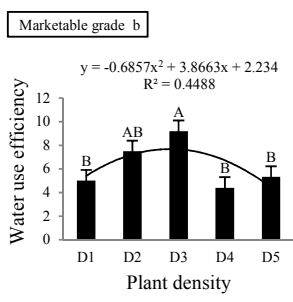

$\mathrm{k}$

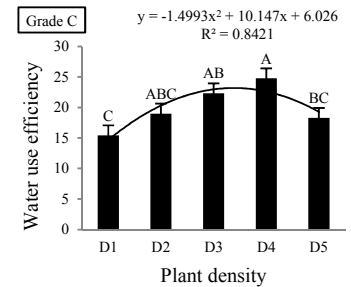

d

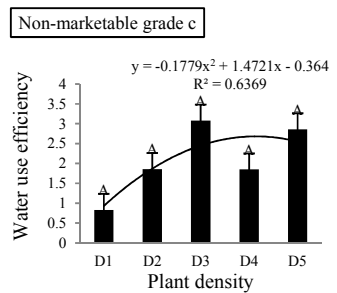

$\mathrm{h}$

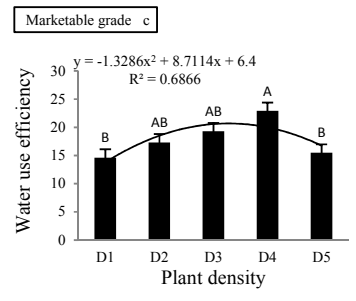

1

Figure 6. Water use efficiency (marketable, non-marketable, grade a\&b\&c) of potato plants grown under different plant density

\section{Discussion}

The regulation of plant density is one of the most important aspects of potato production management because it affects the cost, growth, yield, and quality of the crop (Bussan et al., 2007). The effect of plant density on the morphological characteristics of potato plants essentially results from competition for resources, including light, water, and nutrients. The finding that plant height increased at higher plant densities may be caused by higher competition for sunlight among plants that are grown closer together. A reduction in the amount of light that reaches plants causes the accumulation of auxin, which is a major growth hormone that stimulates cell division and enlargement, and thus increases the height of plants; whereas the higher levels of light that reach plants at lower densities destroy auxin, causing them to be shorter (M. Ghobadi \& M. Ghobadi, 2010). It was also found that plant height increased with wider inter-row spacing's in plants that were grown at the same density. This may be due to these plants having more opportunity to obtain sufficient nutrients and moisture due to less resource competition, which may have favored greater levels of vegetative growth compared with plants that were grown with narrower inter-row spacings. This is consistent with the findings of Akassa et al. (2014) who showed that plants grown at the widest spacing were significantly taller than those grown at the closest spacing.

Fresh and dry mass production were higher in plants that were grown at a low plant density than in those that were grown at a high plant density, possibly due to the former experiencing lower levels of competition for growth requirements. This finding is consistent with that of Getachew et al. (2013), who reported that the above-ground biomass was higher at a low plant density.

The number of branches was significantly reduced with increasing plant density, which supports the previous findings of Ozer (2003) and Jr et al. (2013). Furthermore, the tuber number and yield per plant significantly increased with an increasing number of main stems. Similarly, Lemaga and Caesar (1990) previously showed that the number of main stems was positively correlated with the number of tubers and tuber yield, and negatively correlated with the average tuber weight, and Lemaga and Caesar (1990) and Abrha et al. (2014) showed that the number of tubers was a better determinant of yield than the average tuber weight. This larger number of tubers with increasing plant density may simply be caused by the greater number of plants per hectare 
and is in agreement with the findings of Abrha et al. (2014), who showed that the maximum total number of tubers per hectare occurred at closer plant spacings whereas the lowest number of tubers per hectare occurred at wider plant spacing's.

Approximately $100 \%$ and $202 \%$ more medium and small tubers, respectively, were obtained at the highest plant density than at the lowest plant density. This may be due to the strong competition between plants for nutrients and growth factors at a high density leading to the production of larger numbers of smaller tubers. This result supports the finding of Getachew et al. (2013), who reported that the highest number of small tubers was obtained at closer plant spacing's whereas the lowest number was obtained at wider plant spacing's.

The weight of tubers tended to be higher in plants that were grown at a low density. This may be due to there being a limited number of sinks available per unit area, resulting in plants at a low density experiencing less competition than those at a high density, allowing them to direct more resources to each separate tuber to produce a higher tuber weight (Zabihi-Mahmoodabad et al., 2010). It has previously been shown that there is a significant positive correlation between average tuber weight and yield in potato (Khayatnezhad et al., 2011). Furthermore, Arab et al. (2011) showed that the weight and size of tubers decreases with increasing plant density. Thus, it appears that the increase in tuber number with increasing plant density compensates for the associated decrease in tuber weight, and so was mainly responsible for the effect of plant density on total yield throughout the growing season and the associated increase in productivity per unit area planted. This was in agreement with the findings of Mangani et al. (2015), who emphasized the significance of plant density for increasing the number of potato tubers.

A reduction in specific gravity could be expected at high densities because the intense competition among plants would cause lower amounts of nutrients to be partitioned to each individual plant. However, the specific gravity of tubers was not affected by plant density. This finding is possibly due to this trait being controlled by genetic rather than environmental factors. Similarly, Akassa et al. (2014) and Darvishi et al. (2015) also found that the specific gravity of tubers was not affected by plant density. Good-quality potatoes should have a specific gravity of $>1.08 \mathrm{~g} \mathrm{~m}^{-3}$, with values of $<1.07 \mathrm{~g} \mathrm{~m}^{-3}$ generally being considered unacceptable for processing (Kabira \& Lemaga, 2006). In the present study, plants that were grown at a density of one tuber per dripper (D1 and D4) produced tubers with a specific gravity $>1.07 \mathrm{~g} \mathrm{~m}^{-3}$ despite the difference in plant density, whereas the lowest specific gravities were obtained from plants that were grown at higher densities with two plants per dripper (D2 and D3).

\section{Conclusion}

This study showed that the height, number of branches, and yield of potato cultivar "Spunta" increased with increasing plant density up to 83,200 plants $\mathrm{ha}^{-1}$. The increase in yield was mainly attributable to the higher number of tubers at the plot level, which was able to compensate for the decrease in tuber weight of individual plants. The highest WUE for marketable yield $\left(11.9 \mathrm{~kg} \mathrm{~m}^{-3}\right)$ was obtained at the highest plant density, whereas the lowest WUE $\left(7.5 \mathrm{~kg} \mathrm{~m}^{-3}\right)$ was obtained at $41,600 \mathrm{plants} \mathrm{ha}^{-1}$. However, the lowest percentage of marketable yield $(79.5 \%)$ was obtained at the highest plant density.

\section{References}

Abrha, H., Belew, D., \& Woldegiorgis, G. (2014). Effect of inter and intra row spacing on seed tuber yield and yield components of potato (Solanum tuberosum L.) at Ofla Woreda, Northern Ethiopia. Afr. J. Plant Sci., 8, 285-290. https://doi.org/10.5897/AJPS2014.1153

Akassa, B., Belew, D., \& Debela, A. (2014). Effect of inter and intra row spacing on potato (Solanum tuberosum L.) seed and ware tuber seedling emergence and establishment at Bako, Western Ethiopia. J. Agron., 13, 127-130. https://doi.org/10.3923/ja.2014.127.130

Allen, R. G., Pereira, L. S., Raes, D., \& Smith, M. (1998). Crop evapotranspiration-Guidelines for computing crop water requirements. FAO Irrigation and Drainage Paper 56. FAO, Rome.

Amara, D. G., \& Mourad, S. M. (2013). Influence of organic manure on the vegetative growth and tuber production of potato (Solanumtuberosum varspunta L.) in a Sahara desert region. Intel Journal Agric Crop Sci, 5, 2724-2731.

Arab, H. R., Afshari, H., Sam, D. M., Laei, G., \& Toudar, S. R. (2011). The effect of planting date, depth and density on yield and yield components of potato in Shahrood (Iran). JRAS, 7, 141-149. 
Arsenault, W. J., LeBlanc, D. A., Tai, G. C., \& Boswall, P. (2001). Effects of nitrogen application and seedpiece spacing on yield and tuber size distribution in eight potato cultivars. Am. J. Potato Res, 78, 301-309. https://doi.org/10.1007/BF02875695

Bussan, A. J., Mitchell, P. D., Copas, M. E., \& Drilias, M. J. (2007). Evaluation of the effect of density on potato yield and tuber size distribution. Crop Sci, 47, 2462-2472. https://doi.org/10.2135/cropsci2007.01.0026

Calabrese, N. (2011). Patata nel mondo. Collana Coltura \& Cultura, Bayer Crop Science. Bologna, Italy.

Darvishi, B., Mohammadi, H., Kardan, J., Bayati, E. A., \& Sadeghi, A. (2015). The effect of plantlets density and growth mediacomposition on potato mini-tuber production in hydroponic sand culture. Agri. Forest, 61(2), 61-71. https://doi.org/10.17707/AgricultForest.61.2.05

Getachew, T., Belew, D., \& Tulu, S. (2013). Combined Effect of Plant Spacing and Time of Earthing up on Tuber Quality Parameters of Potato (Solanum tuberosum L.) at Degem District, North Showa Zone of Oromia Regional State. Asian J. Crop Sci., 5, 24-32. https://doi.org/10.3923/ajcs.2013.24.32

Ghobadi, M., \& Ghobadi, M. (2010). The effects of sowing dates and densities on yield and yield components of coriander (Coriandrum sativum L.). World Acad Sci Eng Technol, 70, 81-84.

Haddad, M., Bani-Hani, N. M., Al-Tabbal, J. A., \& Al-Fraihat, A. H. (2016). Effect of different potassium nitrate levels on yield and quality of potato tubers. $J$ Food Agric Environ, 14, 101-107.

Institute, S. (2006). SAS User's Guide: Statistics. Sas Inst.

Jr, M. I. F, Abdalla, M. A., Mohamed, M. F., \& Aboul-Nasr, M. H. (2013). Effect of biofertilization on yield and quality of some potato cultivars (Solanum tuberosum L.). IJAFST, 4(7), 695-702.

Kabira, J., \& Lemaga, B. (2006). Potato Processing: Quality Evaluation procedures for research and food industries applications in East and Central Africa. Kenya Agricultural Research Institute, Nairobi, Kenya.

Katerji, N., Van Hoorn, J., Hamdy, A., \& Mastrorilli, M. (2000). Salt tolerance classification of crops according to soil salinity and to water stress day index. Agr Water Manage, 43, 99-109. https://doi.org/10.1016/ S0378-3774(99)00048-7

Khajehpour, M. (2006). Production of industrial plants. Jehad-e. Daneshgahi Isfahan press. Isfahan. Iran, 580, 61-63.

Khayatnezhad, M., Shahriari, R., Gholamin, R., Jamaatie-Somarin, S., \& Zabihi-e-Mahmoodabad, R. (2011). Correlation and path analysis between yield and yield components in potato (Solanum tubersum L.). Middle East $J$ Sci Res, 7, 17-21.

Lemaga, B., \& Caesar, K. (1990). Relationships between numbers of main stems and yield components of potato (Solanum tuberosum L. cv. Erntestolz) as influenced by different daylengths. Potato Res, 33, 257-267. https://doi.org/10.1007/BF02358455

Mangani, R., Mazarura, U., Mtaita, T. A., \& Shayanowako, A. (2015). Growth, yield and quality responses to plant spacing in Irish potato: A review. Afr J Agric Res, 10, 727-730. https://doi.org/10.5897/AJAR2014. 8557

Onunka, N. A., Antai, G., Onunka, B. N., \& Njoku, S. C. (2011). Effect of plant density and land race on the growth and yield of sweetpotato in northern guinea savanna of nigeria. Journal of Agriculture and Social Research, 11(1), 164-172.

Ozer, H. (2003). The effect of plant population densities on growth, yield and yield components of two spring rapeseed cultivars. Plant Soil Environ, 49, 422-426. https://doi.org/10.17221/4151-PSE

Shayanowako, A., Mangani, R., Mtaita, T., \& Mazarura, U. (2014). Effect of stem density on growth, yield and quality of potato variety amethyst. African Journal of Agricultural Research, 9(17), 139-1397.

Zabihi-e-Mahmoodabad, R., Jamaati-e-Somarin, S., Khayatnezhad, M., \& Gholamin, R. (2010). Quantitative and qualitative yield of potato tuber by used of nitrogen fertilizer and plant density. Am Eurasian J Agric Environ Sci, 9, 310-318. 


\section{Copyrights}

Copyright for this article is retained by the author(s), with first publication rights granted to the journal.

This is an open-access article distributed under the terms and conditions of the Creative Commons Attribution license (http://creativecommons.org/licenses/by/4.0/). 